\title{
MisSING The NeT: \\ The LAW AND ECONOMICS OF AlBERTA's NHL Players TAX
}

\author{
DONALD J.S. BREAN AND ALDO FORGIONE*
}

The Province of Alberta has introduced a tax on the income of all NHL players earned in every game played in Alberta. The Alberta government intends to forward the revenues from the tax to the ownership groups of the Province's two NHL teams - the Edmonton Oilers and the Calgary Flames. Reaction to the tax has been harsh. Criticism ranges from allegations of interference with collective bargaining rights to discriminatory treatment of high profile taxpayers in violation of the North American Free Trade Agreement. The NHL Players Tax is designed to take advantage of the practical application of international foreign tax credit and treaty rules to effectively transfer tax revenues from foreign coffers to the Alberta Treasury. After exploring the stated rationale and incidence of the tax, the authors conclude that Alberta's NHL Players Tax is likely to fail to achieve its objectives. Moreover, the tax represents aggressive extension of the province's tax authority with no public benefit.
La province de l'Alberta a introduit un impôt sur le revenu des joueurs de la $\mathrm{LNH}$ pour chaque partie disputée sur le sol albertain. Le gouvernement de l'Alberta a l'intention d'envoyer les revenus provenant de cet impôt aux groupes propriétaires des deux équipes de la LNH de la province, à savoir les Oilers d'Edmonton et les Flames de Calgary. La critique à cet égard a été sévère et a varié d'allégations d'ingérence avec des droits syndicaux au traitement discriminatoire de contribuables notoires en violation avec l'Accord de libre-échange nord-américain. L'impôt payé par les joueurs de la LNH a été conçu de manière à profiter de l'application pratique des crédits d'impôt internationaux et des règles du traité dans le but de transférer efficacement des revenus imposables de coffres étrangers à ceux de l'Alberta. Après avoir examiné la justification de cet impôt et ses incidences, les auteurs concluent que l'impôt albertain pour les joueurs de la LNHn'atteindra vraisemblablement pas son objectif. De plus, cet impot représente un prolongement agressif des autorités fiscales de la province sans présenter aucun avantage pour le public.

\section{TABLE OF CONTENTS}

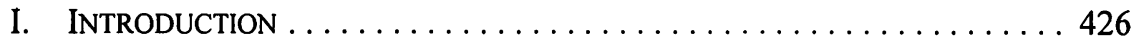

II. AlBerta's TAX ON NHL PlAyERS $\ldots \ldots \ldots \ldots \ldots \ldots \ldots \ldots \ldots . \ldots 27$

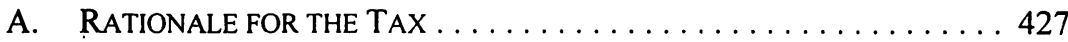

B. Calculation of the NHL Players Tax $\ldots \ldots \ldots \ldots \ldots \ldots 430$

C. REACTIONS .............................. 432

D. CANADIAN TAXATION OF

INTERNATIONAL ATHLETES' INCOME . . . . . . . . . . . . . . . . 433

E. AMERICAN TAXATION OF

INTERNATIONAL ATHLETES' INCOME . . . . . . . . . . . . . . 436

F. TAX TREATIES AND THE TREATMENT

of Professional ATHLETES $\ldots \ldots \ldots \ldots \ldots \ldots \ldots \ldots \ldots . \ldots 48$

G. FOREIGN TAX CREDITS AND THE

CATEGORIZATION OF TAXES

Donald Brean is a professor of finance and economics at the Rotman School of Management, University of Toronto. While writing this article, he was visiting Professor at Ecole Supérieure de Commerce de Paris. Aldo Forgione, LL.B., LL.M., SJD Candidate (University of Toronto, Faculty of Law); Partner, Forgione Law Offices. 


\section{H. THE NORTH AMERICAN FREE TRADE AGREEMENT AND THE}

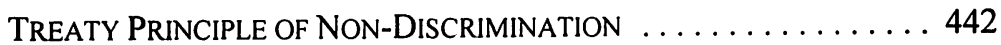

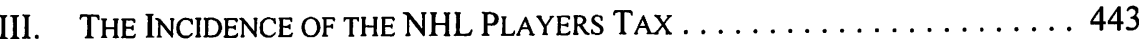

IV. Alberta's TAXING Proposal Misses the Net .............. 446

\section{INTRODUCTION}

Canada's hockey teams - both men and women - were heralded as national heroes when they won gold medals at the 2002 Winter Olympics. While hockey captures the essence of the Canadian identity, the sport is also big business. Like most business, professional hockey often turns to government for favours. However, when the federal government proposed limited financial assistance to several National Hockey League (NHL) franchises in January 2000 , there were virulent reactions from groups opposed to the use of public funds to promote private interests. Most provincial governments thereafter abandoned plans to assist struggling hockey franchises. Alberta is an exception. Alberta enacted tax legislation designed to financially support the province's two NHL teams by taxing athletes playing professional hockey in Alberta.

All NHL players pay a special levy to the Treasury of Alberta amounting to 12.5 percent of the player's income for every regular season game played in Alberta since September, 2002.' The new levy, referred to as the NHL Players Tax, is the first of its kind in Canada. Several jurisdictions in the U.S. tax visiting athletes and entertainers, but none have the design or policy of the NHL Players Tax as enacted in Alberta. The NHL Players Tax levy is targeted exclusively at hockey players and the proceeds are funneled to the owners of Alberta's two NHL teams.

The purpose of this article is to review the premise behind Alberta's NHL Players Tax, to examine the enabling legislation, and to assess both the incidence of the tax and its implications for professional hockey in Alberta. Based on the rationale provided by government officials, we present the Alberta initiative as two integrated components: a surtax on players' income coupled with the redirection of revenues to the owners of select NHL franchises.

The NHL Players Tax involves substantial inter-jurisdictional fiscal interaction. Hence, we begin in the second section with an overview of Canada's national and subnational income tax rules that apply to professional athletes, such as NHL players, who earn income in multiple jurisdictions. We review the residency rules, tax treaty provisions, and tax credit arrangements that typically apply to transient athletes. We then describe how the NHL Players Tax is treated under Canada's bilateral tax conventions and the North American Free Trade Agreement Between the Government of Canada, the Government of Mexico and the Government of the United States. ${ }^{2}$

1 The Alberta Personal Income Tax Amendment Act, 2002, S.A. 2002, c. 6 received Royal Assent on 14 May 2002 [Amendment Act]. The Amendment Act incorporates the NHL Players Tax into the Alberta Personal Income Tax Act, R.S.A. 2000, c. A-30 [Alberta Tax Act]. Alberta Regulation 171/2002 (NHL Tax Regulations) was approved on 7 August 2002 [Regulations]. 
The third section deals with the economic and tax policy implications of the NHL Players Tax, including the question of who will ultimately bear the incidence of this new levy. Under a reasonable set of assumptions concerning the behaviour of players and clubs in response to the tax, the result is a circular flow of fiscal revenue extracted from players and transferred to the clubs. The net effect of this process is an increase in players' pre-tax income sufficient to offset the tax and deprive the clubs of any new net financial resources.

In the final section of the article, we examine whether the policy intention of Alberta's NHL Players Tax is likely to be achieved. The mobility of resources and club capital in professional hockey suggests that the revenue impact of the tax will be mitigated over time and that the incidence of the levy will shift from the players to the clubs and/or fans. We conclude that the NHL Players Tax offers little public gain when balanced against the prospect of material government interference in the marketplace.

\section{Alberta's Tax ON NHL Players}

\section{A. Rationale FOR THE TAX}

Less than ten years ago, one-third of all National Hockey League franchises were based in Canada. ${ }^{3}$ The economics of professional sports in the mid-1990s resulted in popular NHL teams moving from Quebec City and Winnipeg to more lucrative markets in the U.S. ${ }^{4}$ The lure of increasing U.S. government subsidies for professional sport created a vulnerable environment for the remaining Canadian-based hockey teams throughout the 1990s. ${ }^{5}$ In January 2000 , the federal government responded with a proposal designed to provide

3 Eight of the 24 teams in the League in the 1994-95 season were located in Canada. In 2002-2003, only one-fifth or six out of $30 \mathrm{NHL}$ teams were based in Canada. Calgary and Edmonton are two of the Canadian cities that currently host an NHL franchise - Toronto, Montreal, Vancouver, and Ottawa host the remaining Canadian teams.

4 The Quebec Nordiques relocated to Colorado in 1995. The Winnipeg Jets became the Phoenix Coyotes in 1996, leaving the Edmonton Oilers as the only remaining team in the NHL from the defunct World Hockey Association (WHA). The demise of the Winnipeg franchise demonstrated the financial direction of the NHL: "Small markets and small arenas, which may sell out or come close every game just are not welcome anymore. They are not ... economically viable" (Greg Gayden, "Winnipeg Jets," online: neutralhockeyzone.com <www.neutralzonehockey.com/winn.htm>).

5 Over 20 professional sports facilities were built in the U.S. in the 1990s, many relying on some degree of public assistance; see John R. Dorocak, "Tax Advantages of Sports Franchises: The Stadium" State Tax Notes, 20 (1 January 2001) 55; Dennis Coates \& Brad R. Humphreys, "The Stadium Gambit and Local Economic Development" Regulation 23:2 (2000) 15. Under U.S. federal income tax law, the interest income on bonds issued by state or local governments is exempt from taxation in the hands of the bond-holder. By effectively reducing the costs of raising capital, tax-exempt bonds have been widely used by U.S. municipal and local governments to finance the construction of arenas and other facilities to entice prospective professional sports teams; see Kevin Green, Benjamin Klein \& Brian Lebowitz, "Using Tax-Exempt Bonds to Finance Professional Sports Stadiums" State Tax Notes 14 (11 May 1998) 1553. There has been considerable discussion of the private ownership versus public interest conflict in professional sports in the past decade in the U.S. See generally Joanna Cagan \& Neil de Mause, Field of Schemes: How the Great Stadium Swindle Turns Public Money into Private Profit (Monroe, Me.: Common Courage Press, 1998); Roger G. Noll \& Andrew Zimbalist, eds., Sports, Jobs, and Taxes: The Economic Impact of Sports Teams and Stadiums (Washington, D.C.: Brookings Institution, 1997). 
conditional financial support to several Canadian NHL franchises. ${ }^{6}$ Following a backlash from media, citizens and politicians - an outcry against public funds flowing to hockey clubs at a time when social programs were being severely cut - the federal government retracted its offer of financial assistance shortly after its announcement.

Against this background, the Province of Alberta introduced the NHL Players Tax proposal in its Budget Speech of March 2002 ${ }^{7}$. The format of Alberta's tax-based assistance plan differed materially from the scuttled federal grant-based initiative. Alberta proposed a mechanism to assist that province's struggling NHL teams by imposing a tax on the income of hockey players playing in Alberta and then channelling the revenues from the new tax to the owners of the NHL teams in Edmonton and Calgary. ${ }^{8}$ The legislation giving effect to the NHL Players Tax was incorporated into Alberta's personal income tax laws in May 2002 with the Regulations and the tax taking effect at the start of the 2002-2003 NHL season. ${ }^{9}$

In explaining the policy rationale of NHL Players Tax, Alberta Finance Minister Patricia L. Nelson said the province was allowing Alberta's NHL clubs to "in effect tax themselves, or their own players, to support their own teams." ${ }^{.0}$ Since the levy is designed as a new surtax on the player's income, there would be no direct revenue loss to the federal government or the province. Furthermore, the prevailing belief of government and team officials appears to be that the NHL Players Tax would raise revenues for Alberta's two NHL teams without alienating fans through higher ticket prices."

The NHL Players Tax is one of several initiatives that currently provide financial assistance to owners of the NHL teams resident in Alberta. The NHL team owners and the National Hockey League Players' Association (NHLPA) have collectively developed two internal plans designed to provide financial assistance to qualifying Canadian teams in the NHL. The Currency Stabilization Program and the Canadian Currency Equalization Plan are separate schemes found in the current NHL's Collective Bargaining Agreement. The

6 The federal government proposed to offer limited grants and loan guarantees with stringent conditions to Canada's NHL team owners. For a critique of the federal proposal, see Walter Robinson \& Michael Taube, "Bailing Out NHL Teams is Way Offside," Editorial, National Post (5 January 2000) Al6. Alberta, Legislative Assembly, Budget 2002: The Right Decisions for Challenging Times, (19 March 2002), online: Government of Alberta <www.finance. gov.ab.ca/publications/budget/budget2002/>. In a document released with its Budget papers, the Alberta Finance Department explained the tax as a way of providing the NHL teams in Calgary and Edmonton "with additional revenue for operational purposes, while not costing the general public any money" (Government of Alberta, Backgrounder, "NHL Players Tax" (19 March 2002) [Backgrounder]). The provisions establishing the NHL Players Tax became effective upon proclamation of Amendment $A c t$, which occurred on 14 May 2002: s. 19(3) of the Amendment Act. Subsection 48.6(a) of the Act provides that the NHL Players Tax shall apply to the 2002 taxation year, but only with respect to games played after 31 August 2002.

10 Cited in Darcy Henton, "Oilers, Flames players will pay brunt of new pro tax" (19 March 2002), online: Canoe <www.canoe.com>.

1 According to the most recent NHL Team Marketing survey, the Edmonton Oilers had the lowest ticket prices among all 30 NHL clubs during the 2002-2003 hockey season (see "National Hockey League teams have held prices in check for this season" (9 October 2002), online: Team Marketing Report $<w w w . t e a m m a r k e t i n g . c o m / a r t i c l e \_d e t a i l s . c f m ?$ article_id=66>). Nonetheless, the belief is that the Edmonton club would not be able to increase revenues through further ticket price increases; see Shane Holladay, "Oilers Tickets to go up if NHL Players' Tax axed" (6 June 2002), online: Canoe $<$ www.canoe.ca> . 
Currency Stabilization Program provides annual grants to Canadian NHL teams that satisfy certain criteria, such as season ticket sales and advertising revenues. ${ }^{12}$ The Currency Equalization program provides assistance to those Canadian teams that are in the bottom onethird of the league in terms of annual revenues with equalization applying only to the team's restricted free agents. ${ }^{13}$ The objective of the NHL plans is to allow qualifying Canadian teams to better compete financially with U.S. clubs. In addition to these NHL initiatives, in early 2002 the Government of Alberta introduced a public lottery designed to raise further revenues for Alberta's two NHL teams. ${ }^{14}$ The use of lottery funds, a sharply regressive form of taxation, to support the Oilers and Flames represents a government shift in public assistance away from the usual recipients of gaming receipts (charities and non-profit organizations) to private benefactors (owners of professional sports teams).

With the introduction of the NHL Players Tax, the Alberta government has dramatically increased the level of public assistance for professional hockey in the province. The new surtax on players' incomes is expected to raise an additional $\$ 6$ million per season, to be divided equally between the franchises in Calgary and Edmonton. ${ }^{15}$ The NHL Players Tax is viewed as an innovative mechanism that allows Alberta's NHL teams to compete with their more financially secure American and Canadian big-city counterparts. The Alberta government maintains that the NHL Players Tax achieves its objectives without violating the non-discrimination provisions of the NAFTA. ${ }^{16}$ Representatives from Alberta's two hockey clubs as well as executives from several other professional hockey franchises hailed the introduction of the NHL Players Tax as assistance to Canadian sports teams that does not raid

12 The Calgary Flames, Edmonton Oilers, Ottawa Senators, and Vancouver Canucks receive from $\$ 2.5$ to $\$ 3$ million USD each year under the plan, "which was instituted six years ago to help ease the pain of a weak Canadian dollar"( Pierre Lebrun, "TV deal, CBA, skyrocketing salaries to blame for NHL's financial mess" (9 January 2003), online: Yahoo Canada Sports <ca.sports.yahoo.com/030109/6/ r9sa.html >). All four of these teams received $\$ 2.7$ million USD last season. "To qualify for the program, Canadian teams had to sell at least 13,000 season tickets or be among the lowest revenue-generating clubs in the league" after demonstrating material efforts to attract corporate support (ibid.). "Toronto and Montreal have never qualified for the plan because their revenues are too high. In fact, the Habs and Leafs have to contribute to the plan to help out their Canadian cousins" in the same manner as all of the American clubs (ibid.).

13. This plan allows some Canadian teams, such as the Calgary Flames, to compete with other clubs when signing free agents, but fails to help the owners of the Toronto and Montreal NHL franchises that face similar or greater payroll challenges as a result of the difference between the value of the Canadian and U.S. currencies (see Rick Charlton, "A Tale of Two Cities" (9 May 2002), online: Calgarypuck.com <www.calgarypuck. com/Charlton_050902.htm>, noting how the Calgary Flames, but not the Montreal Canadians, have benefited from both NHL currency assistance programs in 2002).

14 The Breakaway to Win lottery, which was introduced in January 2002, is a special ticket lottery operated by the Western Canadian Lottery Commission, the umbrella organization for lotteries conducted in Alberta, Saskatchewan, and Manitoba (online: Breakaway to Win Lottery $<w w w . b r e a k a w a y t o w i n . c o m>)$. The clubs enthusiastically support the return of the $\$ 10$ scratch-to-win lottery for the 2003 hockey season because the proceeds raised from the lottery go to the Calgary Flames and Edmonton Oilers (see "Oilers-Flames 'Breakaway to Win' Lottery Bigger and Better," online: Edmonton Oilers Hockey Club <www.edmontonoilers.com/misc/breakawaytowin.htm>).

is See Backgrounder, supra note 8 . Approximately $\$ 3$ million will be paid in the first year of the plan to each of the Calgary Flames and Edmonton Oilers after annual administration costs (estimated at $\$ 150,000)$ are deducted from the aggregate amount of revenues raised by the Tax. It is difficult to fathom how the Alberta Treasury proposes to calculate "administration costs." While personal income tax collection is a federal responsibility pursuant to current shared tax collection agreements, the administration of the NHL Players Tax may be isolated from usual tax collection mechanisms. 
the public purse. ${ }^{17}$ The Honourable Ralph Klein, Premier of Alberta, anticipates that other provinces with NHL franchises will promptly follow the Alberta tax initiative. ${ }^{18}$ Although other provincial governments have not yet opted to pursue Alberta's lead, the issue of public assistance for professional hockey was catapulted to the forefront with the bankruptcy filings in January 2003 of the Ottawa Senators and the Buffalo Sabres. ${ }^{19}$ The economic rationale for the NHL Players Tax seems more compelling now than ever before.

\section{B. Calculation of the NHL Players tax}

Under Alberta's new legislation, every player in the National Hockey League playing in Alberta is subject to the NHL Players Tax. Players are required to pay the tax as long as they are on an NHL team's roster regardless of whether the athlete actually plays or not. ${ }^{20}$ The amount of tax to be paid by each player is determined by multiplying the NHL hockey income that the player earns from all games played in Alberta during the regular season by 12.5 percent. ${ }^{21}$ The calculation applies regardless of where the player maintains permanent residence in Canada.

The actual amount of NHL Players Tax payable varies from player to player, according to their salaries and the number of games played in Alberta. In October 2002, the Alberta Government explained some of the particular nuances that are unique to the calculation and

Representatives from Edmonton Oilers, Calgary Flames, and Vancouver Canucks claim that the Alberta tax plan will effectively assist small-market Canadian franchises without tapping into general public revenues (see John Cotter, "Alberta to bring in tax on visiting NHL players to help Oilers, Flames" (5 March 2002), online: Yahoo Canada Sports <ca.sports.yahoo.com/020306/6/km8u.html>).

Ibid.: "I'm sure that other provincial jurisdictions that have NHL teams will look at it as well, based on the Alberta model," Premier Ralph Klein declared in reply to a query as to whether he believes other Canadian teams will decide to follow Alberta's lead.

After the Regulations for the NHL Players Tax were enacted, Quebec's Finance Minister indicated that Quebec would not be following the Alberta initiative because of the perceived administrative difficulty of applying the tax and concerns that the structure of the tax plan would contravene the provisions of the NAFTA. See Canadian Press, "Quebec rejects tax on NHL Players" (October 5, 2002), online: TSN.ca $<$ www.tsn.ca>. In the same week in January 2003, the Ottawa Senators and Buffalo Sabres each filed for bankruptcy protection in their respective jurisdictions. The perception among most NHL observers is that extenuating circumstances, not the economics of professional hockey, contributed to the demise of these two franchises. The difficulties faced by the Buffalo Sabres were closely connected to the illegal business dealings of its ownership group, whereas the Ottawa Senators were besieged by financing costs associated with the Corel Centre. See Lebrun, supra note 12, citing Don Meehan, NHL player representative, who declared that in "Ottawa's case, it was a very poor business model to begin with. And the accumulation of debt hasn't allowed it to continue." See also Cotter, supra note 17, noting that J.P. Barry, president of IMG Hockey, also stated that "[i]f you look at it really closely we've got fundamental ownership structure problems in both Buffalo and Ottawa... particularly in Ottawa, Rod Bryden has tried for many years now to get out from the original flawed structure."

The tax legislation applies to participants as well as to any player on the roster of an NHL team that is in an Alberta facility in which an NHL game is being played for all or part of the game, even though the player may not be participating in that game (see s. 48.1(2) of the Alberta Tax Act, supra note 1). Practices and pre-season games are not taxed. It is intended that the tax levy apply to all players on an NHL team's 23-man active roster. Players on the disabled list may have to pay the tax if they are required to be at the hockey rink for a game played in Edmonton or Calgary.

21 Section 48.4 of the Alberta Tax Act, ibid. The legislation expressly provides that the NHL Players Tax shall commence after 31 August 2002 and shall continue in effect until at least 31 December 2005 (ibid., s. 48.6). Tax did not become payable until the 2002-2003 NHL regular season started on 9 October 2002. 
collection of the NHL Players Tax. ${ }^{22}$ Basically, a player's taxable salary for a game day is equal to the player's base salary divided by the number of calendar days in the NHL regular season. ${ }^{23}$ In order to determine the amount of income to be allocated to the NHL player's Alberta hockey services, the legislation relies on the tabulation of duty days spent in the province. $^{24}$

The calculation of Alberta "NHL hockey income" is based on the determination of the player's base salary for the season. Signing bonuses, deferred compensation, and performance incentives are not included in the determination of the amount of the player's salary subject to the NHL Players' Tax. ${ }^{25}$ It is possible for a hockey contract to be structured in a manner that uses alternative income-sourcing methodologies to minimize the ultimate tax burden to the player. ${ }^{26}$

Hockey players under contract to Alberta's two NHL teams pay considerably more NHL Players Tax than other players in the League. The Oilers and Flames play half of their regular season games at home as well as at least two or three games each season as a visitor in the other Alberta rink. Edmonton and Calgary hockey players are taxed on the basis of at least 43 "game days" each regular season compared to players on non-Alberta teams that, at most, play only four or five times per season in Alberta. According to Alberta's tax authorities, the NHL Players Tax amounts to an additional average levy equal to 3.06 percent of the base salary of each Oilers and Flames player. ${ }^{27}$

The NHL Players Tax disproportionately increases the tax burden faced by players on Alberta's two NHL teams. To illustrate this point, let us compare the situation for Edmonton's goaltender, Tommy Salo, with that of Curtis Joseph of the Detroit Red Wings.

"NHL Players Tax Overview" (31 October 2002), online: Government of Alberta $<$ www.revenue.gov.ab.ca/publications/tax_rebates/nhl/overview.html .

The NHL Tax Regulations, s. 2(2), provides that the "NHL hockey income in Alberta" with respect to an NHL player is the sum of the player's taxable salary for all game days in the season with the calculation of game-day income based on the number of calendar days in the season (e.g., 180 days) and not the number of games in the regular season (i.e., 82).

24 The concept of duty days, based on the idea that income earned by the athlete is earned throughout the service period of the contract, is used by Canadian and U.S. tax authorities to distinguish income earned by professional athletes performing services in Canada from those athletes performing services in the U.S. (see Robert E. Beam, Stanley N. Laiken \& Daren A. Raoux, "The Taxation of Non-Resident US Athletes Employed By Canadian-Based Professional Sports Teams: Attracting Athletes to Canada," (1999) 47 Can. Tax J. 305 at 309-10). For discussion of the duty-days concept and related issues, see generally Greg J. Gartner, "Current Issues in the Taxation of Artists and Athletes," 1996 Prairie Provinces Tax Conference (Toronto: Canadian Tax Foundation, 1996).

A signing bonus, which generally represents an amount received by an athlete as an inducement to sign a contract to perform future services, is also subject to special treatment under most of Canada's bilateral tax treaties (e.g., Paragraph 4 of Article XIV of the Canada-United States Tax Convention). For a discussion of how signing and performance bonuses and deferred compensation arrangements can be structured to minimize the general tax liability of a professional athlete subject to taxation in Canada, see Beam et al., supra note 24, 314-35.

Holladay, supra note 11. The Alberta Finance Department claims that Edmonton and Calgary hockey players earning $\$ 1.5$ million (CDN) will pay nearly $\$ 44,000$ on account of the NHL Players Tax while a player earning $\$ 4.7$ million (CDN) a year will pay about $\$ 131,000$ extra as a result of the new tax (Henton, supra note 10). 
Salo earned a base salary of approximately $\$ 3.5$ million for the $2002-2003$ season $^{28}$ while Joseph received a salary of $\$ 8$ million. ${ }^{29}$ Since Edmonton played 43 regular season games in Alberta during the 2002-2003 regular season, Salo incurred an NHL Players Tax liability of over $\$ 105,000$ or slightly more than 3 percent of his total base salary for the season. ${ }^{30}$ By comparison, Joseph had to pay NHL Players Tax of approximately $\$ 16,000$, or 0.2 percent of his total salary because the Detroit Red Wings visited Alberta on only three occasions during the 2002-2003 regular season. ${ }^{31}$

The NHL Players Tax represents a surtax imposed by Alberta on the income of professional hockey players. The levy is on top of federal, provincial, state, and other special income taxes incurred by every NHL player. The impact of the tax is mitigated by the fact that Alberta has the lowest provincial income tax rate in Canada and one of the lowest combined federal and provincial/state rates in the NHL. ${ }^{32}$ Nonetheless, the NHL Players Tax represents an increased tax burden of about 3 percent of the total salary of players on the Edmonton Oilers and Calgary Flames.

\section{REACTIONS}

Not surprisingly, the NHL Players Tax has its detractors. So far, the strongest criticism has been from the NHL player's union, which argues that the new tax interferes with existing employer-employee relationships. The NHLPA filed a formal letter of complaint with the Alberta Finance Minister as well as with the NHL several weeks after the legislation was passed by the Alberta Legislative Assembly. ${ }^{33}$ The NHLPA argued that the NHL Players Tax violates the existing collective bargaining agreement that they have with the NHL. It was felt that the Alberta tax plan would constitute a windfall for the two NHL teams based in Alberta at the expense of all players already bound to professional contracts. ${ }^{34}$

"Money Matters," The Globe and Mail (10 October 2002) at S2. All salaries are reported here in U.S. dollars (USD).

National Hockey League Players Association, "Player Bio: Curtis Joseph," online: National Hockey League Players Association <www.nhlpa.com/Content/the_players/player_biol asp?ID:2724>.

This estimated tax liability for Salo is based on a conservative calculation of duty days. Duty day calculations could be much higher for Alberta hockey players if pre-season training camps, practice days, and off days are taken into account because it is likely that the majority of such days would be spent in the home team's city or in a nearby facility. See Beam Laiken \& Raoux, supra note 24 at 31011 .

Most veteran and goalie contracts provide for the payment of the stipulated base salary regardless of whether the goalie or player actually participates in the NHL game. Since all player salaries in the NHL are denominated in U.S. currency (USD), the Act provides for teams to remit the tax to the Alberta Treasury in USD on behalf of the players.

Top income earners are subject to a lower combined federal-provincial tax burden in Alberta than in any other province in Canada. The top marginal personal income tax rates in 2002 for the provinces with NHL teams are Quebec (48.22 percent), Ontario (46.41 percent), British Columbia (43.7 percent), and Alberta (39.0 percent).

The NHLPA filed a formal complaint against the NHL Players Tax on 3 June 2002. The NHL did not present any arguments at the hearing of the NHLPA grievance because it felt that the players' case lacked merit in that it challenged a government tax initiative; "Hockey Tax Dispute in hands of Arbitrator" (28 October 2002), online: Street \& Smith's Sports Business Journal <www.sports businessjournal.com>.

Player representatives criticized the tax plan as an "outrageous" attempt to transfer resources from players to a select group of employers. See Ted Saskin, senior director at the NHLPA, as quoted in W. Goldstein, "Tax Dispute Could be Taste of Future for NHL Players" (25 October 2002) online: 
Many critics claim that the NHL Players Tax is discriminatory because it is aimed exclusively at hockey players. ${ }^{35}$ The tax does not apply to NHL coaches, trainers, broadcasters, advertisers, or other individuals and businesses that derive income as a result of Alberta NHL games. Furthermore, professional hockey players on Alberta's teams bear a disproportionate burden relative to other athletes as a result of the NHL Players Tax.

The Government of Alberta has been criticized as behaving in a high-handed manner in its announcement of the new tax levy and the ensuing debate. Even though the NHLPA indicated early on that it felt that the proposed levy infringed upon existing contractual arrangements of NHL players, the government enacted the legislation in the midst of the NHL playoffs without further consultation regarding the tax plan with the NHLPA or other player representatives. ${ }^{36}$ The NHL Players Tax received Royal Assent on May 14, 2002 within two months of the initiative having been introduced. Since the Province of Alberta was proceeding under its constitutional tax authority, it was not legally obligated to respond to the ensuing NHLPA grievance.

\section{CanAdian TAXation OF INTERnATIONAL ATHLETES' INCOME}

Professional athletes are subject to taxation in Canada if they are considered residents of Canada or if they earn income from a Canadian source. While the tax liability of a Canadian resident is based on the individual's worldwide income, ${ }^{37}$ non-residents of Canada are liable for Canadian income tax only on income from a source within Canada. ${ }^{38}$ Where a nonresident athlete receives income or salary from a sports team based in Canada, Canadian tax authorities treat the athlete's remuneration as employment income from a Canadian source. ${ }^{39}$ So any salary, wages, or other remuneration paid to an NHL player by a Canadian-based hockey team would constitute employment income for Canadian tax purposes and form part of the athlete's taxable income in Canada.

CBS.SportsLine.com <www.cbs.sporstline.com/nhl/story/5831597>, who described the NHL Players Tax as "outrageous":

We know of no situation where a private company can go to a government to effectively get their wage bill reduced, which is what has happened here.... This is taking money from an employee and sending it right back to his employer. It basically changes what the employer and employee have agreed to on their wage contract.

The NHL Players Tax is perceived as discriminatory by players and player representatives because it is targeted only to NHL players, and because the bulk of the tax load is borne by 50 players in Alberta (see Scott Cruickshank, "Millionaires on Ice cool to taxing situation: Being singled out not fair, Calgary players argue" (21 March 2002) and Scott Cruickshank, "NHLPA protests Alberta Levy" (5 June 2002) online: Canada.com <www.canada.com/sports/hockey>).

36 The rapid enactment of the tax legislation surprised many of the players most affected by the levy (Cruickshank, ibid., citing Craig Conroy of the Calgary Flames, a native of Potsdam, New York: "I didn't really hear about it and, all of a sudden, it goes through. If this was in the U.S., this might take five years to pass. It just doesn't seem like things can get done that quick. It's a tax out of the blue, and you're going to lose some money. It's just weird how quickly things happen."). Sections 2(1) and 3 of the Income Tax Act, R.S.C. 1985, c. 1 (5th Supp.) [Federal Act].

38 Non-residents are subject to tax in Canada pursuant to s. 2(3) of Part I of the Federal Act. Section 115 of the Federal Act provides that non-residents are taxable in Canada if they are "employed in Canada" and income is attributable to the duties of the office or employment performed by them in Canada (ibid.).

39. M.N.R. Interpretation Bulletin IT168R3, Athletes and players employed by football, hockey and similar clubs, (13 May 1991) confirms that team athletes are to be treated as employees for tax purposes. 
Tax payable by an NHL player is determined by the Federal Act, which includes guidelines for the computation of income from employment. All income derived from Canadian sources including employment income, signing bonuses, endorsement revenues, dispositions of taxable capital property, and investment income with a source in Canada is subject to taxation in Canada on a net basis under Part I of the Federal Act. Canada's provinces also impose income tax on individuals who are resident and earn income in the province. Under the tax collection agreements, all provinces except Quebec allow federal agencies to collect both federal and provincial personal income taxes. ${ }^{40}$ Tax rates vary from province to province with Alberta currently having the lowest top marginal income tax rate in Canada. Whether NHL players continue to enjoy preferential tax treatment in Alberta now that the NHL Players Tax is in effect will depend on whether the athlete is a resident of Canada, whether or not he plays for a team based in Alberta, and whether the player can claim a foreign tax credit on those taxes paid by him to the Alberta Treasury.

The majority of hockey players currently in the NHL were born in Canada. ${ }^{41}$ The National Hockey League is an intensely international organization with an increasing number of hockey players born and raised in countries such as Sweden, Russia, Finland, Slovakia, Czech Republic and the U.S. ${ }^{42}$ Accordingly, the nuances of Canada's international tax laws are of considerable importance in understanding the design of Alberta's NHL Players Tax. The new tax levy is designed to take advantage of the foreign tax credit mechanisms adopted by most tax jurisdictions. As a result, foreign residents may be entitled to a deduction or credit from the amount of taxes payable to their home country equal to the full amount of Alberta's NHL Players Tax paid.

Canada's tax laws, like those of most other countries, place great emphasis on the determination of the individual taxpayer's place of residence. An athlete is considered to be a resident for Canadian tax law purposes if he is permanently or "ordinarily resident" in Canada, as determined by reference to the particular circumstances of the individual. Canadian tax authorities consider a professional athlete to be a permanent Canadian resident for tax purposes if the athlete maintains a dwelling, furnishings, and other property in Canada suitable for year-round occupancy, or has a spouse or dependents in Canada ${ }^{43}$ For the foreign athlete to be considered "ordinarily resident" in Canada under the Federal Act, the individual

As of 1 January 2002, all of the provinces - except Quebec - have moved away from charging their provincial tax as a percentage of the federal tax payable towards the federal tax-on-income method. Alberta recently implemented a single rate system for calculating the personal income tax liability of Alberta residents. Section 65 of the Alberta Tax Act affirms that existing tax collection agreements will continue to be relied on by the province for sharing and adjustment of income taxes among participating Canadian jurisdictions.

A total of 590 Canadians spent time in the NHL during the 2001-02 season representing 55 percent of the total 1068 NHL players that season. In 1981 (twenty years earlier), Canadians accounted for 83 percent of all NHL Players. See D'Arcy McGrath, "The Globalization of Hockey" in The Sports Forecaster Hockey Magazine (Toronto: 2002) at 16.

Ibid.: aside from the 590 Canadians in the NHL last year, there were 308 Europeans, 168 Americans, and 2 players from other areas of the world.

4.3 See Revenue Canada Interpretation Bulletin IT-221R3 (Consolidated), 21 December 2002, which indicates that Canadian tax authorities will give considerable weight to factors such as the maintaining of personal property or societal ties to Canada as facts that demonstrate an individual's residency in Canada. 
must demonstrate a regular and lengthy nexus to Canada. ${ }^{44}$ The cases have defined ordinarily resident as "the place where in the settled routine of his life, he regularly, normally or customarily lives" and include an individual's connections, commitments, property, investments, or employment. ${ }^{45}$ The determination of the location of the permanent residence of most NHL athletes will depend on the particular facts surrounding each player.

An individual who is physically present in Canada for an extended period of time may be deemed a resident of Canada under certain provisions of the Federal Act. Basically, an individual could be treated as a resident of Canada if the individual was physically present in Canada for 183 days or more even if he or she did not maintain a permanent residence within the country during the tax year. ${ }^{46}$ This "sojourning rule" would not typically apply to the NHL player that does not spend considerable leisure and off-season time in Canada. ${ }^{47}$ The provisions dealing with part-year residence in Canada, though, have particular importance for professional hockey players that are traded or change teams partway through a taxation year. Where an NHL player is a resident of Canada for only part of the year and a permanent resident of another country for the balance of the taxation year, all income earned by the athlete from all sources during the period of time the athlete was considered a resident of Canada is subject to income taxation in Canada ${ }^{48}$ In some cases, the apportionment of tax liability will depend on the number of days that the foreign resident was physically present in Canada for the purpose of attributing the player's hockey remuneration to sources in Canada, the U.S., and elsewhere. ${ }^{49}$

Section 250(3) of the Federal Act provides that reference therein to a person resident in Canada includes a person who was ordinarily resident in Canada at the relevant time.

Canadian courts consider the following circumstances, among others, as evidence of a taxpayer's residence: residence of the individual's family, club memberships, bank accounts, taxpayer's mailing address, employment, and location of taxpayer's investments and property (Thomson v. M.N.R., [1946] S.C.R. 209; The Queen v. K.F. Reeder, [1975] C.T.C. 256 and Lee v. M.N.R., [1989] T.C.J. No. 1023 $(\mathrm{QL})$ ).

The physical presence test (also referred to as the "sojourning" rule), set out in paragraph 250 (1)(a) of the Federal Act, supra note 37 provides that a person shall be deemed to be resident in Canada throughout the taxation year if the person "sojourned in Canada in the year for a period of, or periods the total of which is, 183 days or more."

4 While it is possible for the deemed residency provisions of the Federal Act to apply to foreign players in the NHL, it seems that most NHL players do not stay long enough in their city of employment to satisfy the physical presence test. Even though the length of the NHL season from pre-season practices through to the end of the Stanley Cup playoffs may go beyond 183 days, NHL players, like most professional team athletes, play half of their games away from home. So, in order for a foreign player to be physically present in Canada in total for a period of 183 or more days, the NHL player would have to structure his off-season pursuits in a manner encompassed by the deemed residency provisions of the Federal Act. For a review of how professional athletes can locate their off season regimen to reduce their U.S. tax burden, see Jeffrey Adams, "Why Come To Training Camp Out of Shape When You Can Work Out in the Off-Season and Lower Your Taxes: The Taxation of Professional Athletes" (1999) 10 Ind. Int'l \& Comp. L. Rev. 79.

The general rule for determining income and expenses of a part-time resident taxpayer of Canada is found in s. 250(2) of the Federal Act, supra note 37. Basically, if the individual is resident in Canada for part of the year and resident elsewhere for the remainder of the year, then the individual will be treated in the same manner as a full-time resident of Canada for the period of the taxation year that the taxpayer was considered as a resident of Canada.

Paragraph 153(1)(a) of the Federal Act, ibid. and s. 101 of the Regulations to the Income Tax Act, C.R.C., c. 945 require Canadian sports teams to withhold and remit income taxes on behalf of the players employed by the team. In M.N.R., Opinion Letter 9601625 , "Income of non-resident actors and athletes" (28 May 1996), Revenue Canada provided the following statement to assist teams in 


\section{E. AmERICAN TAXation Of INTERnational ATHLETES' INCOME}

Most NHL players play for teams based in the United States. American federal income tax rules are similar to those in Canada, with the major exception being that the U.S. taxes the income of its own citizens regardless of where the income is earned or where the taxpayer lives. United States citizens and residents, however, receive a foreign tax credit against their U.S. tax liability for income taxes paid to foreign governments.

NHL players who are neither residents nor citizens of the U.S. will still be liable for U.S. tax if they perform services in the U.S. or earn income from an employer or other source located within the U.S. ${ }^{50}$ Since Alberta's NHL Players Tax could be considered an income tax payable to a foreign government, it is useful to briefly explore whether many NHL players would be treated as residents of the U.S. for income tax purposes.

An individual who is a legal or permanent resident of the U.S. at any time during the calendar year is considered a U.S. resident for federal income tax purposes. ${ }^{51} \mathrm{~A}$ foreign NHL player may be considered a resident of the U.S. for income tax purposes if the player is physically present in the U.S. for an extended period of time. ${ }^{52}$ Under U.S. tax law, athletes must include all income from endorsements, appearances, signatures, likenesses, and other personal services rendered in the U.S. in the taxpayer's gross income. ${ }^{53}$ Where the taxpayer

estimating the amount of tax to be withheld at source:

The apportionment for athletes should reflect the actual number of days an athlete was present in Canada in a team's season beginning with the first day of pre-season training camp until the last day on which his team plays in a play-off game. Where an athlete spends a part of a day in Canada, such day would be considered a day present in Canada. This method applies to regular seasonal salary and performance bonuses based on performance over the entire season. Other remuneration in respect of athletic services may require the use of a different formula.

See ss. 2(d), 871, 877 and 7701(b)(1)(B) of Internal Revenue Code 26 U.S.C. (2000) [U.S. Code]. The U.S. Code refers to foreign resident taxpayers as non-resident aliens.

s1 In addition to citizens and permanent residents of the U.S., s. 7701(b)(3)(c) of the U.S. Code provides that a nonresident may be considered a U.S. resident for tax purposes if the individual holds or applies for an alien registration card (i.e. a "green card") during the calendar year. In lieu of obtaining a green card, some foreign athletes choose to obtain a temporary work permit that allows the athlete to work in the U.S. for up to one year. See Stephanie C. Evans, "U.S. Taxation of International Athletes: A Reexamination of the Artiste and Athlete Article in Tax Treaties," 29 George Washington J. of Int'l Law \& Economics (1995) 297 at 300.

52 See para. 7701(b)(3) of the U.S. Code which sets out the deemed residency presence requirements for foreign individuals. A taxpayer will be treated as a resident of the U.S. if the taxpayer is "present in the United States on at least 31 days during the calendar year" and "the sum of the number of days on which such individual was present in the United States during the current year and the [two] preceding calendar years ... equals or exceeds 183 days." Basically, U.S. tax authorities count each day that the individual was present in the U.S. in the current taxation year as one full day with each day of presence in the U.S. for the first preceding calendar year counting as one-third of a day and each day of presence in the U.S. for the second preceding taxable year counting as one-sixth of a day.

Ibid., s. 61. Compensation received from professional teams, whether a salary or a performance bonus, is taxable in the year it is received (26 C.F.R. s. 1.61-2(a) (2003)). Bonuses that form part of an athlete's contract and do not require the performance of services at any time may not be treated as "wages" and therefore may not be subject to income tax withholding. American courts have confirmed these principles in two prominent cases involving NHL players. In Stemkowski v. Commissioner of Internal Revenue, 690 F.2d 40 (2d Cir. 1982), the Second Circuit court determined that the player could not include off-season days in total days compensated since the salary was based on the NHL season. In Linseman v. Commissioner of Internal Revenue, 82 T.C. 514 (1984), the Tax Court held that a signing 
earns income or incurs expenses in two different countries, such as NHL athletes playing hockey games in both the U.S. and Canada, U.S. tax law requires the taxpayer to allocate his income and expenses from U.S. sources and from foreign sources. ${ }^{54}$ The determination of the U.S. tax liability of a non-resident NHL player involves a calculation of the number of days the athlete was physically present in the U.S. and an allocation of the athlete's earned income to the period of time that the player was present within the U.S. ${ }^{55}$

In addition to taxation at the U.S. federal level, most athletes are subject to sub-national income tax based on state and local graduated rates. ${ }^{56}$ While an NHL player will not generally be considered a resident of a state if he is there for strictly temporary or transitory purposes, it is not uncommon for NHL players to encounter problems of competing tax claims and double-taxation of certain income by different U.S. states. ${ }^{57}$ NHL players may be required to remit tax not only to the state of the player's employer but also in the state or states where the player performs his services. ${ }^{58}$ The wide scope of the income tax laws of

bonus was not a covenant not to compete (as was the position of the IRS at that time), but rather an inducement to perform future services. It was determined by the Court that the signing bonus should be apportioned to U.S. sources based on the number of games the NHL team was scheduled to play in the U.S. during the first season of the contract.

Section 861(a)(3) of the U.S. Code, ibid. provides, in part, that compensation for labour or personal services performed in the U.S. shall be treated as income from sources within the U.S. U.S. Code s. 862(a)(3) provides that "compensation for labour or personal services performed without the United States" shall be treated as income from sources outside the U.S., while 26 C.F.R. s. 1.861-4(b) (2003) provides a mechanism that allows the athlete to allocate the income earned by the player between U.S. sources and foreign sources (ibid.).

s5 See Daniel Sandler, The Taxation of International Entertainers and Athletes (The Hague: Kluwer Law International, 1995) at 153 . The determination of the amount of income earned by an NHL player that is not a resident of either Canada or the U.S. will often depend upon the terms of the individual's employment contract. If the contract specifies an allocation of income between sources in the U.S. and Canada, then the Internal Revenue Service demands that the allocation be reasonable. If no contractual allocation exists, then under U.S. tax law the percentage of the athlete's compensation categorized as U.S.-source income can be calculated based on the total number of days the taxpayer performed services in the U.S. as a fraction of the total number of days over which the compensation was paid to the taxpayer (see U.S. Code, ibid., 26 C.F.R. s. 1.861-4(b) (2003)).

56 See Adams, supra note 47 at 89-91. The calculation of the amount of U.S. tax payable by an NHL player will vary depending on the state where the athlete is considered to reside. For instance, California has one of the highest state tax rates in the country while Florida does not impose any state income tax at all. State residence is usually determined by reference to where the athlete is permanently domiciled. Problems arise when a state like New York subjects non-resident athletes to state income tax even if the athlete is employed by an out-of-state team and only visits the state to play a road game. The calculation of the tax base could differ from state to state. For instance, California tax authorities calculate an athlete's taxable income based on the number of days physically present in the State (including practices and training days) instead of utilizing the games played approach used in other jurisdictions. See John Salmas, "Professional Athletes Taxed to Death? Even They Can Strike Out!!!" (1997) 4 Sports Law. J. 255 at 270-71.

Several years ago, Robert Goodenow, executive director of the NHLPA, indicated that state tax rules resulted in onerous filing requirements for NHL players: "Some players are required to file six, seven, eight tax returns because of the ramping up of local tax office," quoted in E. Douglas Banks, "Boston Attorney Seeks Consistency in Athlete Taxation: Says Pro Athletes Can Be Taxed in Every State Where They Play Games" Boston Business Journal (March 1999) 5:11. The filing burden has increased exponentially over the past few years, as a huge number of U.S. jurisdictions levy some form of visiting players tax now. Of all the sports leagues in North America, the NHL is the worst in that regard, with 27 out of the 30 teams residing in states that tax part of the income earned by NHL players. By comparison, the NFL has 25 franchises in visiting tax territory and Major League Baseball has 24 clubs in states that tax visiting players (with Puerto Rico recently welcoming Expo players and other baseball 
some U.S. states means that many NHL players are compelled to file an income tax return and remit tax in multiple jurisdictions. The NHL Players Tax represents an additional administrative tax obligation for NHL players. ${ }^{59}$

\section{F. TaX Treaties and the Treatment of Professional Athletes}

Bilateral tax treaties modify a nation's tax treatment of its residents' foreign income as well as the taxation of the domestic source income of non-resident taxpayers. Canada is a party to over 80 bilateral tax treaties, including probably every jurisdiction that is home to an NHL player. Tax treaties often attempt to resolve a number of issues, such as the elimination of discriminatory tax treatment and the prevention of tax evasion through the promotion of information exchanges between tax authorities and the allocation of tax jurisdiction between nations. Where an individual falls within the broad domestic rules that classify him or her as a resident of two or more countries, the tax treaty provides a means of resolving conflicting residency rules. In most of Canada's bilateral tax treaties, the residency of the taxpayer is determined by referring to the location of the taxpayer's permanent residence or "habitual abode."

Tax treaties often contain a provision that deals specifically with income earned by professional athletes. ${ }^{61}$ For instance, the Canada-U.S. Income Tax Convention ${ }^{62}$ distinctly taxes the income derived by athletes from professional sports leagues, such as the NHL, that have regular season games in both Canada and the U.S. ${ }^{63}$ The Convention basically assigns

players with the introduction of a 20 percent tax on each athlete's income for Expo games played in Puerto Rico). See Darren Rovell, "Baseball, not players, receive tax break from Puerto Rico" (7 April 2003), online: Tax Foundation <www.tax foundation.org/press-baseball.html>.

Unlike the Alberta NHL Players Tax, most U.S. jurisdictions tax only visiting entertainers and athletes. All NHL players must ensure that the Province of Alberta receives the forms and tax due to it under the NHL Players Tax legislation: s. 3(3) of NHL Tax Regulations, supra note 7. NHL teams must remit the prescribed amount of tax accompanied by a return in prescribed form to the Provincial Minister on a monthly basis (Regulations, ibid., s. 4).

See e.g. Convention between Canada and the United States of America with Respect to Taxes on Income and on Capital, 26 September 1980, Can. T.S. 1984 No. 15, as amended by First Protocol signed on 14 June 1983, by Second Protocol signed on 28 March 1984, by Third Protocol signed on 17 March 1995 and by Fourth Protocol signed on 29 July 1997 [Canada-U.S. Income Tax Convention]; Article IV sets out several rules that provide for the individual to be treated as a resident of only one treaty partner country. The treaty first makes reference to where the individual has a permanent home. If the taxpayer has a permanent home in both Canada and the U.S., then tax authorities will look to where the individual maintains an habitual abode. If the person's habitual abode cannot be readily determined, then the tax treaty provides for the individual to be a resident of the Contracting State of which he is a citizen, provided that if the person is a dual citizen of Canada and the U.S., then it will be left to the tax authorities to decide the individual's residency by mutual agreement.

See Organization for Economic Cooperation and Development, Thin Capitalisation and Taxation of Entertainers, Artistes and Sportsmen (Paris: OECD, 1987). The OECD Model Convention and most of Canada's bilateral tax treaties contain a special provision dealing exclusively with international athletes and entertainers (or artistes). In many instances, such provisions stipulate that the employment income of those taxpayers be taxed in a manner similar to the taxation of income from other dependent service activities (ibid.).

6.3 Article XVI, paragraph 4 of the Canada-U.S. Income Tax Convention, ibid. provides that paragraphs 1 and 2 of Article XVI of the Convention, dealing with "Artists and Athletes," are not to apply to teams or athletes playing in a professional sports league with games in both Canada and the U.S., such as the NHL. Effectively, this provision permits source taxation of the employment income of NHL athletes 
primary taxing jurisdiction over an NHL player's hockey salary to the country where the player performs his services, but restricts source taxation of signing bonuses and other inducement income to a maximum rate of 15 percent. ${ }^{64}$ If the athlete is not a resident of either Canada or the U.S., then it is necessary to refer to the particular provisions of the tax treaty involving the home country of the foreign athlete. In one of the only Canadian cases to be adjudicated concerning the treaty provisions dealing with athletes, a Canadian court determined that the bonus paid to an NHL player resident in a foreign country must be treated separately from the player's salary income. Pursuant to the applicable tax treaty provision, the bonus would then be subject to taxation only in the player's country of residence. ${ }^{65}$

In circumstances where the pertinent tax treaty does not distinguish income earned by professional athletes from other types of employment income, which is the approach effectively adopted in the Canada-U.S. Income Tax Convention in respect of NHL athletes, it is necessary to rely upon the text of the treaty article that deals with income derived from the performance of dependent personal services. As a general rule, income from the performance of personal services is subject to taxation by the country where the activities giving rise to the income take place. For instance, the Canada-U.S. Income Tax Convention provides that a taxpayer's income from the performance of dependent personal services will be taxed in the country where the services are performed if the remuneration is greater than $\$ 10,000$ (which is the case for NHL players), or if the taxpayer is physically present in the country where the services are performed for more than 183 days in the taxation year and the employer is not a resident of the country where the services are performed. ${ }^{66}$

\section{G. Foreign TAX CRedits ANd THE CATEgorization of TAXeS}

Most countries strive to eliminate or mitigate double taxation by either exempting foreign source income from taxation or by allowing their own residents to claim tax credits on account of income taxes paid to foreign governments. The residency of an NHL player will determine whether the player receives a foreign tax credit in connection with the payment of the NHL Players Tax.

Canadian residents earning employment income in the U.S. will typically be required to pay income tax to U.S. federal and state governments. Canada allows a credit against total Canadian tax liability for the amount of U.S. and other foreign income taxes paid by the

(see Francois Chagnon, "Cross-Border Taxation of Artists, Entertainers, and Athletes" in Canadian Tax Foundation, Report of Proceedings of the Forty-Ninth Tax Conference, 1997 (Toronto: Canadian Tax Foundation, 1998) 24:1 at 24:5).

Paragraph 4 of Article XVI of the Canada-U.S. Income Tax Convention, ibid., which was added by the First Protocol to the Convention, indicates that any amount paid to the athlete as an "inducement to sign an agreement relating to performance of services" (e.g. a signing bonus) may be taxed by the source country at a rate not to exceed 15 percent. former Winnipeg Jets goaltender was exempt from taxation in Canada under paragraph 4 of Article XIII of the Canada-U.S.S.R. Treaty. 
Canadian resident. ${ }^{67}$ Similarly, where a non-resident of Canada pays taxes on account of hockey income earned in Canada, the jurisdiction where the player is resident will generally provide a credit to the taxpayer for the amount of Canadian taxes paid by the player. ${ }^{68}$ Canadian-resident NHL players cannot claim a foreign tax credit for the NHL Players Tax because Alberta is not a foreign jurisdiction for Canadian taxpayers. ${ }^{69}$

Although bilateral tax conventions do not typically bind political subdivisions of the contracting states, tax treaties do reaffirm that the foreign tax credit rules of most jurisdictions would also apply to income taxes levied by sub-national governments, such as a state, province, or locality. ${ }^{70}$ Under existing international tax rules, only income taxes and not foreign social security and payroll taxes, such as U.S. social security taxes and Canadian Pension Plan deductions, tend to be creditable against the domestic tax liability of resident taxpayers. ${ }^{71}$ This distinction carries particular importance for the purpose of understanding the design and the incidence of the NHL Players Tax. As a direct tax on income - computed on the basis of a player's salary pro-rated to the amount of his play in Alberta - the NHL Players' Tax would qualify for foreign tax credit under most bilateral tax treaties, even though the tax is levied at the provincial level.

The amount of tax credit granted by the resident jurisdiction depends largely on the particular tax rules of the country or state where the athlete is resident. The foreign tax credit regimes of Canada, the U.S., and most European countries are subject to limitations that basically ensure that the amount of domestic taxation of domestic source income is not reduced by the credit provided on account of taxes paid to a foreign government.

NHL clubs withhold and remit income taxes on behalf of all players employed by the team. Where a Canadian team remits tax on behalf of a U.S. resident, the U.S. Treasury will

Section 126 of the Federal Act, supra note 37 sets out Canada's foreign tax credit provisions. Basically, the amount of the credit is limited to the lesser of (a) the amount of foreign taxes paid for the year on the foreign source income, and (b) the amount of Canadian tax otherwise payable on the foreign income.

In Backgrounder, supra note 8, the Alberta government states that "[t]he United States would likely provide a foreign tax credit for U.S. residents. Credits for players resident in other countries would be dependant on tax laws in their respective countries."

While Alberta's tax legislation provides for the introduction of a tax credit system with other provinces that may decide to introduce a similar tax, the provision is ineffective as no other province currently levies any tax similar to the NHL Players Tax.

For instance, Article II, para. 2(a) of the Canada-U.S. Income Tax Convention, supra note 60 states that in Canada's case, the treaty only applies to "the taxes imposed by the Government of Canada under the Income Tax Act." However, para. 7 of Article XXIV (Elimination of Double Taxation) provides:

For the purposes of this Article, any reference to "income tax paid or accrued" to a Contracting

State shall include Canadian tax and United States tax, as the case may be, and taxes of general application which are paid or accrued to a political subdivision or local authority of that State, which are not imposed by that political subdivision or local authority in a manner inconsistent with the provisions of the Convention and which are substantially similar to the Canadian tax or

United States tax, as the case may be.

See, for example, Article XXIV of the Canada-U.S. Income Tax Convention, supra note 60 at para. 1, which provides that "the United States shall allow to a citizen or resident of the United States... as a credit against the United States tax on income the appropriate amount of income tax paid or accrued to Canada"; in the case of Canada, at para. 2(a), "income tax paid or accrued to the United States on profits, income or gains arising in the United States ... shall be deducted from any Canadian tax payable in respect of such profits, income or gains." 
grant a foreign tax credit to the U.S. taxpayer. Some U.S. jurisdictions also grant credits against the tax liability of U.S. resident hockey players for various U.S. state and local taxes. ${ }^{72}$ Where a U.S. NHL team remits tax to the U.S. Treasury on behalf of a Canadian resident, Canada will accede a foreign tax credit to the Canadian resident for the amount of U.S. taxes paid by the player. Alberta residents and other residents of Canada, however, do not receive any credit against Canadian tax liability for any NHL Players Tax paid by the athlete.

To summarize the application of the foreign tax credit to NHL players tax positions, the Canadian perspective is as follows:

a) A Canadian resident on the roster of a Canadian-based NHL team will have income deducted at its source by the Canadian employer. The player's world income will be taxed by Canada. The player is eligible for a tax credit against his Canadian tax liability for U.S. income tax paid by the player in connection with services rendered in the U.S., but no credit will be provided for the NHL Players Tax.

b) A non-resident athlete on the roster of a Canadian-based NHL team pays tax to Canada on all income earned in Canada since the athlete's employer is resident in Canada. The athlete may also be liable for U.S. income tax calculated by applying U.S. tax rates to the NHL income of the athlete depending on the tax treaty, if any, between the player's country of residence and the U.S. The player's country of residence will typically provide a credit to the taxpayer for income taxes paid by the athlete to foreign governments, including the amount of NHL Players Tax paid to the Alberta Treasury on behalf of the player.

c) A Canadian resident on the roster of a U.S.-based NHL team is liable for Canadian income tax on income earned in Canada for games played or other related services rendered in Canada. The U.S. Treasury will withhold income tax at its source because the athlete's salary is paid by a U.S. employer. The taxpayer must report his worldwide income to Canada and pay the balance, if any, of income tax due after receiving a foreign tax credit on account of income taxes paid to the U.S. No credit or allowance for the NHL Players Tax will be provided to the Canadian resident.

d) A U.S. resident or any non-resident of Canada that is employed by a U.S.-based team may be liable for Canadian tax on all income derived from the performance of services in Canada depending on the provisions of the pertinent tax treaty between Canada and the athlete's country of residence. The player will not receive a foreign tax credit from Canada, but will likely receive a tax credit from his home country for the amount of income tax paid (including NHL Players Tax) to any Canadian governments.

Since most jurisdictions in the U.S. have entered into reciprocity agreements that credit the amount of taxes paid by the player as a visiting athlete, U.S. resident athletes may not incur an increased tax burden as long as the amount of visiting taxes paid by the athlete does not exceed his home state income tax liability. See Rovell, supra note 58 at 2 . However, the tax burden faced by the athlete would increase if he resided in a no-tax state, such as Florida. Hockey players with the Florida Panthers and Tampa Lightning may not be able to deduct the visiting taxes they pay because their home state does not levy a state income tax. 
Foreign residents that play hockey in Alberta may not reap the benefit of the province's relatively low income tax rate because the taxpayer's country of residence will levy its income tax on the player's worldwide income and give a credit for foreign taxes actually paid by the taxpayer. The NHL Players Tax would constitute an increase in the amount of taxation of the athlete's employment income at its source, but would not necessarily increase the overall tax liability of the non-resident player. In such cases, the tax credit rules effectively provide Alberta with additional taxing room at the expense of the foreign treasury.

\section{H. THE NORTH AMERICAN FREE TRADE AGREEMENT AND THE TREATY PRINCIPLE OF NON-DISCRIMINATION}

Canadian governments inclined to provide financial assistance to private businesses that compete with U.S. businesses must be concerned with the provisions of the $N A F T A{ }^{73}$ Indeed, the Alberta Finance Department went out of its way when introducing the NHL Players Tax to state that the new tax would not violate the provisions of the NAFTA. ${ }^{74}$ The Alberta government's position was that as long as all NHL players were treated in the same fashion, the tax would be consistent with the NAFTA.

In fact, the $N A F T A$ does not change or modify Canadian income tax provisions. For the most part, the NAFTA accedes issues pertaining to the taxation of cross-border income to the bilateral tax conventions of its member nations. ${ }^{75}$ Tax treaties have pre-eminence in the event of inconsistencies with the provisions of the NAFTA ${ }^{76}$ Taxes on cross-border services are protected to a limited extent by the National Treatment provisions found in the NAFTA. ${ }^{77}$ However, there is nothing in it that appears to prevent a Contracting State, or a political subdivision such as Alberta, from enacting a tax advantage relating to the performance of services within its jurisdiction. Since income tax measures are generally beyond the scope of the NAFTA, the Alberta government was not under any trade obligation to enact or restrict the scope of its income tax measures as long as the new tax did not violate the nondiscrimination provisions of Canada's tax treaties. ${ }^{78}$

Supra note 2.

Backgrounder, supra note 8: "Why doesn't this new tax violate NAFTA? All NHL players are being treated in the same fashion, which complies with NAFTA."

Article 2103, at para. 2 of the NAFTA, supra note 2 provides: "[n]othing in this Agreement shall affect the rights and obligations of any Party under any tax convention. In the event of any inconsistency between this Agreement and any such convention, that convention shall prevail to the extent of the inconsistency." As a result of this provision, the bilateral tax conventions of the NAFTA's member countries govern the taxation of international income between member states.

This distinction is important in instances where the tax treaty provides exclusive bilateral advantages under a tax treaty in apparent contradiction or conflict with the most favoured nation principles espoused throughout the NAFTA. Article 2103(4)(c) of the NAFTA preserves the priority of the tax treaty provisions even if the convention accords fiscal advantages to its signatories contrary to the spirit of the NAFTA, ibid.

Ibid., Art. 2103 (4)(a) provides that the National Treatment clauses set out in the agreement "shall apply to taxation measures on income ... that relate to the purchase or consumption of particular services." Ibid., Art. 2103, at para. 1 provides that "[e]xcept as set out in this Article, nothing in this Agreement shall apply to taxation measures." New tax measures are exempt from the NAFTA as long as the tax rules are "aimed at ensuring the equitable and effective imposition or collection of taxes and [do] not arbitrarily discriminate between persons, goods or services of the Parties or arbitrarily nullify or impair benefits accorded" under the NAFTA (ibid., Art. 2103(4)(g)). However, taxing authorities are bound by the national treatment provisions typically found in bilateral tax treaties, such as those set out in 
The most pertinent concern of the NHL Players Tax is not the tax measure itself, but the channelling of government tax revenues to private businesses. It is irrelevant whether all NHL players are taxed in an equal manner. The critical issue is whether all NHL teams are treated in an equal or similar manner by governments. The NAFTA compels Canadian governments to accord "national treatment" to foreign and national businesses within the state. National treatment with respect to a state or province means treatment no less favourable than the most favourable treatment accorded by each state or province to any like or competing providers of goods or services. ${ }^{79}$ The redirection of tax revenues by a provincial government to private interests represents a variation in the delivery of financial assistance to local businesses. Alberta's decision to pay the proceeds of the NHL Players Tax (but not the tax itself) to the owners of two professional hockey teams could be subject to challenge as a violation of the national treatment principles set out in the NAFTA.

\section{The InCIDENCE OF THE NHL Players TAX}

A naive interpretation of the incidence of the NHL Players Tax might suggest that the players alone begrudgingly bear the tax. Under this simple-minded perspective, the net effect of the new levy would be to reduce players' incomes in proportion to their ice time in Alberta. Tax revenues would flow to team owners. Fans would be indifferent as they are not being asked to incur any additional costs. The reality is that the effects of the NHL Players Tax are unlikely to unfold in this manner.

It is more reasonable to view the NHL Players Tax as a differential payroll tax that players will avoid by refusing to sign with Alberta teams unless they are compensated for a tax that fellow hockey players elsewhere do not have to pay. In unravelling the incidence of the tax, we can simplify the discussion by assuming that there are two kinds of hockey players those that play for Calgary or Edmonton, and those that do not. The fact that non-Alberta players are subject to the NHL Players Tax on their in-Alberta playing time is a relatively minor complexity that can be addressed as a cost of earning NHL income for all hockey players. The challenge is to determine who bears the incidence of the tax burden imposed on Alberta players.

An old and true adage in tax incidence analysis is that you cannot tax anything that can move. Taxpayers adjust to taxes by moving away from them in one way or another. The more mobile the intended tax base, the more likely it is that targeted taxpayers will avoid the tax entirely. The tax base in this case is the income that hockey players' earn for their play in Alberta. Income is determined by the contractual arrangements between the team and the player and is influenced by the values determined within the market for players. One way to mitigate liability in respect of the NHL Players Tax would be to shift remuneration from base salary to signing bonuses and deferred compensation arrangements. ${ }^{80}$ By refusing to treat all

Article XXV (Non-Discrimination) of the Canada-U.S. Income Tax Convention, supra note 60. of National Treatment to the provision of services within a province is set out in Art. 1202(2). 
income in a non-neutral manner, the NHL Players Tax provides a financial incentive to players to structure contractual arrangements to avoid the burden of the tax.

The NHL Players Tax is inequitable in that the burden it imposes will become increasingly borne by a shrinking group of hockey players. In the short run, say within a contract cycle, only those players who are immobile or locked into their contracts will bear the tax. Players currently under contract can complain, but their options are limited. In such circumstances, players are stuck with the NHL Players Tax. When new contract negotiations arise, however, Alberta players that have been paying the NHL Players Tax will point out to the Alberta team owners that they - the players - are fiscally penalized relative to players on non-Alberta teams. Each Alberta player will demand a gross pay differential to correct the net differential or they may opt to play for another NHL team. ${ }^{81}$ If the Alberta fiscal penalty is not neutralized by higher pre-tax income, then players have an incentive to opt out of playing for an Alberta team.

Not all players, however, will opt out of playing for Alberta's teams. There are quality differences among professional hockey players. Some players will view the net-of-Alberta hockey salaries as sufficiently attractive to keep them in or draw them to playing for Edmonton or Calgary. The fundamental economic point is that players are paid what they are worth by their employers, the team owners. If Alberta team owners do not compensate their players for the NHL Players Tax, then the players who opt to stay in or move to Alberta would be accepting lower net-of-tax salaries than players elsewhere. Alberta players who absorb the tax thus accept that they are worth less as revenue-generating hockey players than players who receive the same pre-tax salary elsewhere. The professional hockey market dictates that teams that pay lower after-tax salaries will tend to attract lower calibre players.

If Alberta hockey players were to receive systematically lower after-tax incomes than players elsewhere, the long-term effect would be deterioration of the "hockey business" in Alberta. The same is true of every professional sport. So-called "small market cities" are often in chronic financial difficulty. The small market franchise fails and the team relocates to a larger economic market. Canadians have first-hand experience with the economics of the hockey business: Winnipeg lost the Jets to Phoenix and Quebec City lost the Nordiques to Colorado.

Perhaps the NHL Players Tax will not lead to the demise of professional hockey in Alberta. The ultimate result depends on the owners and the fans. Under plausible assumptions in tax analysis, the owners and the fans will bear the brunt of the tax and the players will escape unscathed. Indeed, once the mobility from team to team is taken into account, the logical conclusion is that the final incidence will not fall upon the players. Again, professional athletes know their market value. The only plausible premise is that, in the end,

amount of income tax revenues collected by the respective source and residence jurisdictions, as most bilateral tax treaties distinguish signing bonuses from the treatment accorded to employment income (see Khabibulin v. The Queen, supra note 65).

See Joe McLaughlin, "Puckster tax plan smells like an old jockstrap" (June 7, 2002) Red Deer Advocate at <www.reddeeradvocate.com/editorials>: "The revenue impact [of the NHL Players Tax] will tend to diminish towards zero over time because every player on the Oilers and Flames will seek a raise in pay at contract time to offset its additional costs." 
players of equal ability will receive equal after-tax income regardless of which team pays their salary. Anything, such as the NHL Players Tax, that arbitrarily enters into the equation to compromise that result will be neutralized by a combination of players literally moving away from the tax and/or negotiation of higher pre-tax salaries to offset the tax.

Examined this way, the hard decision then appears to fall on team owners in Alberta. If they intend to compete with team owners elsewhere in, say, Ontario or New Jersey, then Alberta team owners must pay the competitive pre-tax salary that equates their players' aftertax salary with after-tax salaries elsewhere. Otherwise, if Alberta team owners fail to offer competitive pre-tax salaries, they de facto limit their salary offers to levels that are acceptable only to lower quality players at each level of the salary-scale. To the extent that winning hockey games is a matter of commercial consequence, Alberta team owners will be forced to absorb the tax on behalf of the players that they employ.

The next question deals with the team owners' options. What if Alberta team owners opt to ignore the NHL Players Tax in their salary negotiations and, hence, defy the forces of the competitive market for hockey players? Clearly, Alberta team owners will get less player-perpre-tax-dollar than other NHL team owners. The performance of Alberta's hockey teams will suffer to the extent that player compensation and player quality determines the team's performance. Furthermore, where there is a correlation between team performance and team revenues, such as ticket sales and the value of media or advertising rights, the decision to ice a lower calibre squad will adversely impact the economics of the team. Again, for assessment of the incidence of the NHL Players Tax, the view that hockey player quality matters - for the fans and ultimately for commercial survival - is an appropriate working assumption. After all, hockey is professional entertainment. If the team owners in Alberta compromise the quality of hockey by signing or hiring players of lower calibre, fans will lose interest. Attendance will fall, and media revenues will decline as well. The tension between owners, who focus on profits and survival, and fans that desire strong, exciting, and competitive teams, could detrimentally affect revenues, attendance, and television ratings.

Once the economic impact of the decision to reduce hockey quality is properly considered by team owners, it becomes clear that team owners would prefer to pursue other options. The most likely avenue is that team owners will shift the incidence of the NHL Players Tax onto the fans of professional hockey. Private team owners cannot be expected to absorb the tax. The team owners have made investments of capital in their teams. If the team owners are to bear the burden of the tax, the return on capital invested by them in the hockey team will decline. Capital is a mobile factor and, just like athletes, it will seek alternative employment where the return is greater. The reasoning is straightforward: players (labour) and teams (capital) are close complements in the production of hockey entertainment. Subject to an important qualification to be discussed below, the team owners will try to pass the NHL Players Tax on to the fans via increases in ticket prices and the price of media rights. The fans, as a result, will ultimately bear the incidence of the NHL Players Tax. Among players, owners and fans, the fans themselves are the least mobile and, thereby, the most likely to bear the incidence of the NHL Players Tax.

Hockey fans will still have a choice, but it could be a difficult one. Fans will get the quality of team and quality of hockey that they are collectively willing to pay for. There is 
a price point at which higher ticket prices discourage fans from attending hockey games. Once that point is attained and fans withdraw their support, the vicious cycle of deterioration begins.

The qualification that leads one to conclude that the NHL Players Tax will flow through to ticket prices and impose the incidence of the tax on fans involves the use of revenues from the tax. Our discussion has proceeded along the line that players, owners, and fans do not benefit directly from the revenues as is normally the case for most taxes. However, according to the Alberta tax authorities, the revenue from the tax is to flow to team owners in support of Alberta teams that struggle with the "small-market" phenomenon. The redirection of the revenues derived from the NHL Players Tax complicates the analysis of who really bears the tax. In some respects, the government could be perceived as compensating owners for the expectation that players will pass the incidence of the tax onto team owners. If, as in a closed system, the revenue derived from a tax on factors of hockey entertainment flows back into hockey entertainment, then in a real sense nothing happens except a reallocation of money from players to team owners with a little bit lost due to the inefficiency of administering the tax. To understand this seemingly obvious interpretation of a tax combined with targeted revenue redirection, it is necessary to again proceed step-by-step through the above discussion, albeit there are now fewer steps as we are walking in a circle.

Where tax revenue is extracted from the players and handed to the team owners, the players' after-tax income falls and the owners' return on invested capital increases. There is a loss for the players and a gain for the owners. As before, the squeeze on players' after-tax income would induce them to move to teams offering higher after-tax salaries or to negotiate higher gross salaries to remain in Alberta. To the extent that players pursue the former option, and team owners do not adjust salary offers, then the hockey-quality scenarios discussed above come into play. On the other hand, with their budgets enhanced with the transfer of funds from Alberta's tax authorities, the team owners in Calgary and Edmonton would now be in a position to meet the players' demand for higher pre-tax salaries without adversely impacting their pre-NHL Players Tax return on capital. The owners should be prepared to return some of the tax revenues that they indirectly receive to the players that they wish to sign to new contracts. The circularity of the money flow is obvious.

\section{Alberta's Taxing Proposal Misses the Net}

When Alberta Finance Minister Nelson introduced the NHL Players Tax, she indicated that the province was allowing the owners of Alberta's two NHL clubs to "in effect tax themselves, or their own players, to support their own teams." ${ }^{182}$ The Minister described a taxbased arrangement with all the force of law that is intended to realign the finances of the private business of professional hockey.

The design of the NHL Players Tax belies the most controversial aspects of the tax initiative. First, on the revenue-side, it is a surtax on a particular category of income - the earnings of hockey players. In countries with poorly developed income tax systems, this might be referred to as a "schedular" tax, an approach that has long been recognized as a 
capricious, uneven, and opportunistic basis of raising revenue. Second, the tax revenue is "ear-marked" for the hockey clubs. This matching of a specific tax to a specific purpose (for example, gasoline taxes for highway construction) is a fiscal anachronism that ought not to be revived. Good public expenditures ought to be funded from the most neutral and administratively efficient revenue sources. Ear-marking is among the crudest and least imaginative forms of fiscal policy.

The NHL Players Tax could succeed as a fiscal transfer mechanism from foreign government coffers to the Alberta Treasury. However, this represents "tax exporting," a less than admirable tax design feature that might allow Alberta to score a bit of revenue for its hockey clubs at the expense of the irritation, and potential retaliation, of our bilateral tax treaty partners. The key factor will be whether the foreign jurisdiction where the player is permanently resident provides a tax credit equal to the additional tax paid by the player. For many non-residents of Canada, the NHL Players Tax will reduce the players' tax liability to his country of residence. For instance, if we assume that Edmonton Oilers goaltender Tommy Salo is a resident of Sweden and that the combined federal-provincial rate of tax for hockey income earned in Alberta is lower than Sweden's effective tax rate on the world income of its residents, then the addition of the NHL Players Tax would transfer additional tax revenues to Alberta with no additional tax burden being absorbed by Salo.

Canadian residents cannot take advantage of the foreign tax credit rules for the NHL Players Tax. Hockey players resident in Canada incur the full burden of the NHL Players Tax without the tax credit relief enjoyed by foreign residents. Since the amount of tax payable by a player on an Alberta team will be substantially greater than the total amount of tax payable by a visiting player, Canadian residents will be less inclined to play for one of the Alberta teams. If it is an objective of the Alberta Government to encourage professional Canadian hockey players to stay and play in Alberta, it should be noted that the NHL Players Tax creates the opposite incentive. Unless salaries increase to compensate for the additional tax burden, the NHL Players Tax will lead to an outflow of Canadian resident NHL players from Edmonton and Calgary.

Team assistance is a fundamental feature of Alberta's NHL Players Tax initiative. From an economic standpoint, the circular interaction of tax revenues and player salaries lessens the adverse effects of the tax on players while shifting the incidence to the fans and media. Meanwhile the province establishes a dangerous precedent by delivering government assistance through redirection of tax revenues. The decision to channel proceeds of the NHL Players Tax to private interests represents interference with collective bargaining rights. This intrusion into the private sector adds uncertainty to employment relationships in other sectors of the economy. Furthermore, the delivery of grants to private businesses violates the spirit, if not the text, of the non-discriminatory provisions of the NAFTA.

If the government's intention to assist teams in Calgary and Edmonton is separated from the analysis of the tax itself, it would seem that the NHL Players Tax is unlikely to improve the viability of hockey in these two cities. In the first instance, the new levy penalizes current Oilers and Flames players for their loyalty and commitment to an Alberta team. Players who have signed long-term contracts with one of Alberta's hockey teams before the introduction of the NHL Players Tax will have to bear the full brunt of the additional tax levy. Players that 
resign or sign a new contract with an Alberta team would factor the price of the tax into their salary negotiations. Alberta's team owners may not be inclined to increase salaries to offset the incidence of the tax. Private owners may simply pocket the monies for a more favourable return on capital. If total team salaries remain at the same or similar levels, the NHL Players Tax would cause quality players to leave the Alberta teams. NHL players should be expected to move to the jurisdiction where their net income after taxes would be the highest. Alberta becomes an unattractive tax jurisdiction regardless of whether Alberta's top marginal tax rates are, in fact, lower than those in other jurisdictions. Given that Calgary and Edmonton are small-market cities that are unable to pay competitive salaries, this view of Alberta as an unattractive tax jurisdiction may aggravate the flow of quality players away from the province.

The NHL Players Tax is an example of a bad tax plan. The scheme as a whole clearly interferes with collective bargaining rights. The diversion of tax revenues to private employers ought to disturb our notion of fairness. By targeting the tax exclusively to a small and popular sector of economic players with no net public revenue gain, the government is flouting basic tax policy principles. Market forces will absorb the NHL Players Tax in a manner that would contradict the hopes and desires of Alberta's loyal hockey fans. Alberta has taken a shot at boosting hockey in the province, but has missed the net with the NHL Players Tax. 